\title{
Composition, antimicrobial and antioxidant activity of the extracts of Eryngium palmatum Pančić and Vis. (Apiaceae)
}

Research Article

Mirjana D. Marčetić ${ }^{1 *}$, Silvana D. Petrović ${ }^{1}$, Marina T. Milenković ${ }^{\text {, Marjan S. Niketić }}{ }^{3}$

'Department of Pharmacognosy,

University of Belgrade, Faculty of Pharmacy,

11221 Belgrade, Serbia,

2Department of Microbiology and Immunology,

University of Belgrade, Faculty of Pharmacy,

11221 Belgrade, Serbia

${ }^{3}$ Natural History Museum,

11000 Belgrade, Serbia

Received 18 April 2013; Accepted 05 August 2013

Abstract: The chemical composition, antimicrobial and antioxidant activity of Eryngium palmatum, an endemic plant species from the Balkan Peninsula, were investigated. The flavonoids apigenin $\left(9.5 \pm 0.3 \mathrm{mg} \mathrm{g}^{-1}\right)$ and apigenin $7-0$-glucoside $\left(2.4 \pm 0.1 \mathrm{mg} \mathrm{g}^{-1}\right)$ were determined in a methanol extract of aerial parts using HPLC analysis. The methanol extract of roots contained catechin $\left(5.0 \pm 0.1 \mathrm{mg} \mathrm{g}^{-1}\right)$, epicatechin $\left(2.9 \pm 0.1 \mathrm{mg} \mathrm{g}^{-1}\right)$, chlorogenic acid $\left(1.6 \pm 0.0 \mathrm{mg} \mathrm{g}^{-1}\right)$, gallic acid $\left(0.9 \pm 0.0 \mathrm{mg} \mathrm{g}^{-1}\right)$ and rosmarinic acid $\left(0.9 \pm 0.2 \mathrm{mg} \mathrm{g}^{-1}\right)$. GC-FID and GCMS analysis of a chloroform extract of aerial parts showed that the main volatile constituents were falcarinol, linoleic acid, hexadecanoic acid and methyl linoleate (comprising $32.6 \% ; 24.4 \% ; 19.9 ; 13.2 \%$ of the volatile fraction, respectively), while octanoic acid, tetradecanol and dodecanol dominated in the chloroform extract of the roots (34.9\%; $25.8 \% ; 22.2 \%$ of the volatile fraction, respectively). Investigation of antimicrobial activity by broth microdilution showed that the methanol and chloroform extracts of aerial parts and roots exerted a significant effect (MIC 3.5-15.6 $\mu \mathrm{g} \mathrm{mL}^{-1}$ ) against tested Gram-positive and Gram-negative bacteria. The methanol extracts of aerial parts or roots exerted moderate ferric reducing antioxidant power, DPPH radical scavenging activity and hydroxyl radical scavenging activity.

Keywords: Eryngium palmatum • Extracts • Composition • Antimicrobial activity • Antioxidant activity

(C) Versita Sp. z 0.0 .

\section{Introduction}

The genus Eryngium L. (Apiaceae) comprises about 250 species distributed in temperate regions [1]. Some Eryngium species are cultivated as vegetables, ornamental or medicinal plants. In traditional medicine they are used to treat various inflammatory disorders, fever, diarrhea, hypertension, oedema, sinusitis and snake or scorpion bite [2,3]. Previous investigations show that species of this genus contain flavonoids, triterpene saponins, coumarins, rosmarinic acid derivatives, polyacetylenes and essential oils [4-6]. Aquaeous extracts of leaves and flowers of $E$. bourgatii Gouan exhibit antioxidant and anti-inflammatory activity [6], and ethanol extracts of different Eryngium species have anti-inflammmatory and antinociceptive activity [2]. The essential oil of aerial parts of $E$. duriaei J. Gay has demonstrated antifungal activity [7], while the essential oils from E. campestre L., E. thorifolium Boiss. and E. creticum Lam. inhibit the growth of methicillinresistant Staphylococcus aureus strains [8].

Eryngium palmatum Pančić and Vis. is an endemic species of the Balkan Peninsula [9]. The aim of this work was to investigate the composition and antimicrobial and antioxidant activity of extracts of the aerial parts and roots of this plant. Increasing bacterial resistance to commonly used chemotherapeutics requires a constant search for new compounds with new mechanisms of action [10]. Antioxidant compounds may be also valuable since oxidative 
stress presents a risk to human health and can lead to the development of conditions such as cardiovascular diseases and cancer [11]. Plants are one of the most promising sources for discovering novel antimicrobial and antioxidant agents [11,12]. Beside potential therapeutic values, investigations of $E$. palmatum provide valuable information about these vulnerable endemic species, helping to contribute to their future protection and conservation. The composition and antimicrobial and antioxidant activity of $E$. palmatum extracts have not previously been investigated.

\section{Experimental Procedures}

\subsection{Chemicals}

Folin-Ciocalteu reagent, 2,4,6-tripyridyl-s-triazine (TPTZ), 2,2-diphenyl-1-picrylhydrazyl (DPPH), polyvinylpyrrolidone (PVP), 2-deoxyribose and analytical standards gallic acid, (+)-catechin, (-)-epicatechin, chlorogenic acid, rosmarinic acid, apigenin and apigenin 7-glucoside were obtained from Sigma-Aldrich, St. Louis, MO, USA. Thiobarbituric (TBA) and phosphoric acid were purchased from Merck, Darmstadt, Germany; trichloroacetic acid (TCA), ethylenediaminetetraacetic acid (EDTA) and L-ascorbic acid from Lachema, Neratovice, Czech Republic; 2-deoxyribose from Acros Organics, New Jersey, USA. Acetonitrile used for HPLC analysis was obtained from J. T. Baker, Phillipsburg, NJ, USA, HPLC grade. All other solvents and chemicals were of analytical grade. Ampicillin, amikacin and nystatin were purchased from Galenika, Belgrade, Serbia; Müeller-Hinton broth and Sabouraud dextrose broth from Institute of Immunology and Virology Torlak, Belgrade, Serbia.

\subsection{Plant material and extraction procedure}

The aerial parts and roots of E. palmatum were collected in Sićevačka gorge, in Eastern Serbia in April 2007. Identification was confirmed by curator botanist Dr. Marjan Niketić from the Natural History Museum, Belgrade, Serbia and a herbarium specimen was deposited there (2007040201 BEO). The herbal material was air dried, ground to a coarse powder and extracted with chloroform at room temperature. After chloroform extraction, the material was air-dried and extracted with methanol. Solvents were evaporated under reduced pressure at less than $40^{\circ} \mathrm{C}$. Aerial parts yielded $1.02 \%$ of the chloroform extract and $1.35 \%$ of the methanol extract, and roots yielded $6.33 \%$ and $11.22 \%$ respectively. All results are calculated per $\mathrm{g}$ of dry weight of plant extracts (DW).

\subsection{Total phenolic and tannin contents}

The total phenolic and tannin contents in the methanol extracts of $E$. palmatum were analyzed spectrophotometrically by the Folin-Ciocalteu assay. The removal of tannin was achieved with insoluble polyvinylpyrrolidone (PVP) which binds tannins [13]. Total phenolic and tannin contents were expressed as $\mathrm{mg}$ of gallic acid equivalents per $\mathrm{g}$ of dry weight of extract (mg g ${ }^{-1} \mathrm{DW}$; GAE).

\subsection{HPLC analysis of methanol extracts}

HPLC analysis was performed on Agilent 1100, using a Zorbax Eclipse XDB-C18 analytical column $(4.6 \times 250 \mathrm{~mm}$ with $5 \mu \mathrm{m}$ particle size), with photodiode array detector. Samples (10 $\left.\mathrm{mg} \mathrm{mL}^{-1}\right)$ were gradiently eluted with a two phase system, phase A-water/ phosphoric acid (99.97:0.03), $\mathrm{pH} 2.75$ and phase $\mathrm{B}-10 \%$ $A$ in acetonitrile, flow rate of $0.8 \mathrm{~mL} \mathrm{~min}^{-1}$, at $25^{\circ} \mathrm{C}$. Gradient profile was: $0 \min 90 \% \mathrm{~A}, 10 \% \mathrm{~B} ; 5-15 \mathrm{~min}$ $75 \%$ A, 25\% B; $20 \min 70 \%$ A, 30\% B; $25 \operatorname{min~} 50 \%$ A, $50 \%$ B; $30 \min 30 \% A, 70 \%$ B and $35 \min 90 \% A$, $10 \%$ B. Identification of components was performed by comparison of retention time and spectra with representative standards. Quantification of compounds was achieved by construction of the calibration curves of gallic acid, (+)-catechin, (-)-epicatechin, chlorogenic acid, rosmarinic acid, apigenin and apigenin 7-glucoside.

\subsection{GC-FID and GC-MS analysis of chloroform extracts}

The volatile constituents were determined by GC-FID and GC-MS. The GC analysis was performed on Agilent 6890N GC system equipped with 5975 MSD and FID, using a HP-5 MS column ( $30 \mathrm{~m} \times 0.25 \mathrm{~mm}, 0.25 \mu \mathrm{m}$ film thickness). The injection volume was $2 \mu \mathrm{L}$ and the injector temperature was $200^{\circ} \mathrm{C}$ with a $10: 1$ split ratio. Helium was the carrier gas and its flow rate was $1.0 \mathrm{~mL} \mathrm{~min}^{-1}$ (constant flow mode). The column temperature was linearly programmed in the range $60-280^{\circ} \mathrm{C}$ at a rate of $3^{\circ} \mathrm{C} \mathrm{min} \mathrm{m}^{-1}$ and held at $280^{\circ} \mathrm{C}$ for $5 \mathrm{~min}$. The transfer line was heated at $250^{\circ} \mathrm{C}$. The FID detector temperature was $300^{\circ} \mathrm{C}$. El mass spectra $(70 \mathrm{eV})$ were acquired in the $m z-1$ range 35-550. The retention indices were experimentally determined using $n$-alkanes $\left(C_{8}-C_{20}\right.$ and $\mathrm{C}_{21}-\mathrm{C}_{40}$ ), under the same chromatographic conditions. The identification of the compounds was based on the comparison of their retention indices $(\mathrm{RI})$, their retention times $\left(t_{R}\right)$ and mass spectra with those obtained from authentic samples and/or the NIST AMDIS (Automated Mass Spectral Deconvolution and Identification System) software, Wiley libraries, Adams data base and literature [14]. The relative percentages of the identified compounds were computed from the GC-FID peak area. 


\subsection{Antimicrobial activity}

The antimicrobial activity of E. palmatum methanol and chloroform extracts was examined by the broth microdilution method [15] against the eight different laboratory control strains of bacteria and one strain of yeast. Minimal inhibitory concentrations (MICs) were determined according to the Clinical and Laboratory Standards Institute [15]. All tests were performed in Müller-Hinton broth for bacterial strains and in Sabouraud dextrose broth for Candida albicans. Overnight broth cultures of each strain were prepared at a final concentration of $2 \times 10^{6} \mathrm{CFU} \mathrm{mL}^{-1}$ for bacteria, and at $2 \times 10^{5} \mathrm{CFU} \mathrm{mL}^{-1}$ for yeast, in a 96-well microtitre plate. The extracts were investigated in serial doubling dilutions from 1.8 to $100.0 \mu \mathrm{g} \mathrm{mL}^{-1}$. Triphenyl tetrazolium chloride (TTC) was added to the culture medium as a growth indicator $(0.05 \%)$. Microbial growth was determined after incubation at $37^{\circ} \mathrm{C}$ for $24 \mathrm{~h}$ for bacteria, and after incubation for $48 \mathrm{~h}$ at $26^{\circ} \mathrm{C}$ for yeast. The MIC is defined as the lowest concentration of the extract at which the microorganism does not demonstrate visible growth. The MIC of ampicillin, amikacin and nystatin were determined in parallel experiments. All determinations were performed in duplicate; two positive growth controls were included.

\subsection{Ferric reducing antioxidant power}

The total antioxidant potentials of methanol extracts were determined using a ferric reducing antioxidant power (FRAP) assay based on the reduction of ferric ion $\left(\mathrm{Fe}^{3+}\right)$ to ferrous ion $\left(\mathrm{Fe}^{2+}\right)$ and formation of a blue complex $\left(\mathrm{Fe}^{2+}-\right.$ 2,4,6-tripyridyl-s-triazine), which increases absorption at $593 \mathrm{~nm}[16,17]$. The amount of reduced $\mathrm{Fe}^{2+}$ - TPTZ complex was calculated from an equation of the regression line constructed from the absorbance of water solutions of $\mathrm{FeSO}_{4} \times 7 \mathrm{H}_{2} \mathrm{O}(0.1$ $1.0 \mathrm{mmol} \mathrm{L}^{-1}$ ) under experimental conditions. Results are expressed as $\mathrm{mmol} \mathrm{Fe}{ }^{2+} \mathrm{g}^{-1}$ of dry weight of extracts.

\subsection{DPPH radical scavenging activity}

DPPH radical scavenging activity is based on the reduction of the free radical $\mathrm{DPPH} *$ (2,2-diphenyl1-picrylhydrazyl) and decrease of absorbance at

\begin{tabular}{|c|c|c|c|c|c|c|}
\hline & & $\begin{array}{l}\text { Phenolic } \\
\left(\mathrm{mg} \mathrm{GA} \mathrm{g}^{-1}\right)\end{array}$ & $\begin{array}{c}\text { Tannin } \\
\left(\mathrm{mg} \mathrm{GA} \mathrm{g}^{-1}\right)\end{array}$ & $\begin{array}{c}\text { FRAP } \\
\left(\mathrm{mmol} \mathrm{Fe}^{2+} \mathrm{g}^{-1}\right)\end{array}$ & $\mathrm{DPPH}\left(\mathrm{mg} \mathrm{mL}^{-1}\right)$ & $\begin{array}{l}\text { Hydroxyl radical } \\
\left(\mathrm{mg} \mathrm{mL}^{-1}\right)\end{array}$ \\
\hline \multirow{2}{*}{ Methanol extract } & aerial parts & $29.0 \pm 2.0$ & $4.5 \pm 1.0$ & $0.2 \pm 0.0$ & $0.6 \pm 0.0$ & $0.5 \pm 0.0$ \\
\hline & roots & $13.9 \pm 1.0$ & $4.7 \pm 1.0$ & $0.1 \pm 0.0$ & $0.7 \pm 0.0$ & $0.3 \pm 0.0$ \\
\hline Rutin & & - & - & $5.9 \pm 0.0$ & $0.006 \pm 0.0$ & $0.002 \pm 0.0$ \\
\hline
\end{tabular}

Table 1. Total phenolic and tannin contents as mg GA g ${ }^{-1}$, ferric reducing ability (FRAP) as mmol Fe $\mathrm{F}^{2+} \mathrm{g}^{-1}$, DPPH radical and hydroxyl radical

$517 \mathrm{~nm}$ [18]. The $\mathrm{SC}_{50}$ value, which is the concentration of the tested extract that reduces $50 \%$ of the free-radical concentration, was calculated as $\mathrm{mg} \mathrm{mL}^{-1}$ from the plot of logarithms of concentration vs. probits of scavenging effect.

\subsection{Hydroxyl radical scavenging activity}

Hydroxyl radical scavenging activity was determined in a non-site-specific deoxyribose assay. The extract (20 $\mu \mathrm{L}$ of different concentrations) was mixed with $100 \mu \mathrm{L}$ of $4 \mathrm{mmol} \mathrm{L}^{-1} \mathrm{FeCl}_{3}, 100 \mu \mathrm{L}$ of $4 \mathrm{mmol} \mathrm{L}-1$ EDTA, $200 \mu \mathrm{L}$ of $0.05 \mathrm{~mol} \mathrm{~L}^{-1} 2$-deoxyribose, $20 \mu \mathrm{L}$ of $1.5 \% \mathrm{H}_{2} \mathrm{O}_{2}$ and $100 \mu \mathrm{L}$ of $4 \mathrm{mmol} \mathrm{L}^{-1} \mathrm{~L}$-ascorbic acid in phosphate buffer, $\mathrm{pH}=7.4$ ( $4 \mathrm{~mL}$ final solution). The mixtures were then incubated at $37^{\circ} \mathrm{C}$ for $60 \mathrm{~min}$. After addition of $1 \mathrm{~mL}$ of $1 \%$ solution of thiobarbituric acid (TBA) in $0.05 \mathrm{~mol} \mathrm{~L}^{-1}$ $\mathrm{NaOH}$ and $1 \mathrm{~mL}$ of $2.8 \%$ solution of trichloroacetic acid (TCA), the mixtures were heated at $100^{\circ} \mathrm{C}$ for $15 \mathrm{~min}$, and then cooled on ice. Absorbance of the samples was measured at $532 \mathrm{~nm}$ [19]. Rutin was used as the control.

\section{Results and Discussion}

\subsection{Total phenolic and tannin contents}

The composition of methanol and chloroform extracts of $E$. palmatum aerial parts and roots was investigated. The total phenolic content in the methanol extract of aerial parts $(29.0 \pm 2.0 \mathrm{mg} \mathrm{GA} / \mathrm{g})$ was higher than in the methanol extract of roots $\left(13.9 \pm 1.0 \mathrm{mg} \mathrm{GA} \mathrm{g}^{-1}\right.$ (Table 1). The total phenolic content of the methanol extracts of $E$. palmatum were higher than in the previously researched ethanol extracts of $E$. bornmuelleri Nábělek (25.8 mg GA g-1 leaf; $8.9 \mathrm{mg} \mathrm{GA} \mathrm{g}^{-1}$ stem and $3.6 \mathrm{mg} \mathrm{GA} \mathrm{g}^{-1}$ root) [20]. Tannin content was similar in the methanol extract of aerial parts and in the methanol extract of roots $(4.5 \pm 1.0$ and 4.7 $\pm 1.0 \mathrm{mg} \mathrm{GA} \mathrm{g}^{-1}$, respectively).

\subsection{Composition of methanol and chloroform extracts}

The methanol extract of aerial parts contained flavonoids: apigenin $\left(9.5 \pm 0.3 \mathrm{mg} \mathrm{g}^{-1}\right)$ apigenin $7-0$-glucoside

\footnotetext{
scavenging activity as $\mathrm{SC}_{50}\left(\mathrm{mg} \mathrm{ml}^{-1}\right)$ of the methanol extracts of aerial parts and roots of E. palmatum.

DPPH-2,2-diphenyl-1-picrylhydrazyl 
$\left(2.4 \pm 0.1 \mathrm{mg} \mathrm{g}^{-1}\right)$, another apigenin glycoside and also one kaempferol diglucoside (Table 2). Flavonoids were not detected in the methanol extract of roots, which did contain catechin $\left(5.0 \pm 0.1 \mathrm{mg} \mathrm{g}^{-1}\right)$, epicatechin $\left(2.9 \pm 0.1 \mathrm{mg} \mathrm{g}^{-1}\right)$, chlorogenic acid $\left(1.6 \pm 0.0 \mathrm{mg} \mathrm{g}^{-1}\right)$, gallic acid $\left(0.9 \pm 0.0 \mathrm{mg} \mathrm{g}^{-1}\right)$ and rosmarinic acid $\left(0.9 \pm 0.2 \mathrm{mg} \mathrm{g}^{-1}\right)$. The presence of chlorogenic acid was previously reported in the leaves and flowers of E. bourgatii [6], leaves of E. foetidum L. [3] and leaves and roots of E. planum L. [21]. The content of chlorogenic acid in the roots of $E$. palmatum $\left(1.6 \pm 0.0 \mathrm{mg} \mathrm{g}^{-1}\right)$ was higher than the previously reported content of chlorogenic acid in the roots of $E$. planum $\left(0.19 \pm 0.00 \mathrm{mg} \mathrm{g}^{-1}\right)$ [21]. The roots of different species of the genus Eryngium contain rosmarinic acid in the range $0.4-272.0 \mathrm{mg} \mathrm{g}^{-1}$ [5,21]. In the methanol extract of roots of $E$. palmatum a moderate quantity of rosmarinic acid was determined.

The main compounds of the volatile part of the chloroform extract of aerial parts (Table 3) were polyacetylene falcarinol (32.6\%), linoleic acid $(24.4 \%)$, hexadecanoic acid (palmitic acid) (19.9\%) and methyl linoleate $(13.2 \%)$. The volatile fraction of the chloroform extract of roots contained octanoic acid (caprylic acid) (34.9\%), tetradecanol (myristyl alcohol) (25.8\%) and dodecanol (lauryl alcohol) (22.2\%).

\subsection{Antimicrobial activity}

The antimicrobial activity of extracts of $E$. palmatum was investigated against eight bacterial strains and yeast C. albicans (Table 4). The methanol and chloroform extracts showed high antimicrobial activity with MIC values in the range $3.5-15.6 \mu \mathrm{g} \mathrm{mL}^{-1}$. The investigated extracts were active against both Gram-positive and Gram-negative bacteria. Compared to Gram-positive bacteria, Gram-negative bacteria are usually more resistant to commonly-used antibiotics as well as to plant secondary metabolites, having a complex cell wall, which acts as an effective permeability barrier to restrict the penetration of compounds. Furthermore a set of multidrug resistance pumps in their cell wall extrudes toxins across the outer membrane $[11,22]$. The highest antimicrobial activity was obtained with the methanol extract of aerial parts against $M$. luteus (MIC $3.5 \mu \mathrm{g} \mathrm{mL}^{-1}$ ). This effect may be due to its flavonoid content. The methanol extract of aerial parts contained apigenin and its glycosides as well as kaempferol glycoside. Apigenin and kaempferol exert antimicrobial activity [23] and probably have multiple cellular targets. Phenolic compounds inhibit microbial adhesions and inactivate enzymes and cell envelope transport proteins [24]. Apigenin inhibits $E$. coli DNA gyrase and it has been suggested that the $B$ ring of the flavonoids plays a

\begin{tabular}{|c|c|c|c|}
\hline & \multirow[t]{2}{*}{$\mathrm{Rt}^{\mathrm{a}}$} & \multicolumn{2}{|c|}{ Methanol extract } \\
\hline & & aerial parts & roots \\
\hline Gallic acid & 4.1 & $0.9 \pm 0.0^{b}$ & $0.9 \pm 0.0$ \\
\hline$(+)$-Catechin & 7.6 & - & $5.0 \pm 0.1$ \\
\hline Chlorogenic acid & 8.4 & - & $1.6 \pm 0.0$ \\
\hline (-)-Epicatechin & 9.1 & $t$ & $2.9 \pm 0.1$ \\
\hline Kaempferol diglucoside & 9.3 & $+^{c}$ & $-d$ \\
\hline Apigenin glycoside & 10.5 & + & - \\
\hline Apigenin 7-O-glucoside & 16.2 & $2.4 \pm 0.1$ & - \\
\hline Rosmarinic acid & 18.7 & - & $0.9 \pm 0.2$ \\
\hline Apigenin & 27.4 & $9.5 \pm 0.3$ & - \\
\hline
\end{tabular}

Table 2. HPLC analysis of the methanol extracts of aerial parts and roots of $E$. palmatum

a retention time on Zorbax Eclipse XDB-C18 column ${ }^{b} \mathrm{mg} \mathrm{mL}^{-1}$ of dry extract; ' present in investigated methanol extracts; ${ }^{d}$ not detected

\begin{tabular}{c|ccc}
\hline Rla & Compounds & Volatile part of chloroform extract (\%) & roots \\
\hline \hline 1004 & Oerial parts & 2.0 \\
1177 & Octanoic acid (caprylic acid) & $-\mathrm{b}$ & 34.9 \\
1474 & Dodecanol (lauryl alcohol) & - & 22.2 \\
1693 & Tetradecanol (myristyl alcohol) & 4.5 & 25.8 \\
1790 & Pentadecanol & 1.3 & 3.0 \\
1963 & Hexadecanoic acid (palmitic acid) & - & - \\
2035 & Falcarinol & 19.9 & 4.8 \\
2096 & Methyl linoleate & 32.6 & - \\
2130 & Linoleic acid & 13.2 & $\mathrm{t}^{\mathrm{c}}$ \\
\hline
\end{tabular}

Table 3. GC-FID and GC-MS analysis of the volatile part of the chloroform extracts of aerial parts and roots of E. palmatum. 


\begin{tabular}{|c|c|c|c|c|c|}
\hline \multirow{3}{*}{ Microorganism } & \multicolumn{5}{|c|}{$\mathrm{MIC}\left(\mu \mathrm{g} \mathrm{mL^{-1 }}\right)$} \\
\hline & \multicolumn{2}{|c|}{ Methanol extract } & \multicolumn{2}{|c|}{ Chloroform extract } & \\
\hline & aerial parts & roots & aerial parts & roots & \\
\hline Staphylococcus aureus ATCC 25923 & 15.6 & 15.6 & 7.8 & 15.6 & $0.5^{\text {Amp }}$ \\
\hline Staphylococcus epidermidis ATCC 12228 & 7.8 & 7.8 & 15.6 & 7.8 & $1.0^{\mathrm{Amp}}$ \\
\hline Micrococcus luteus ATCC 9341 & 3.5 & 15.6 & 7.8 & 7.8 & $0.5^{\mathrm{Amp}}$ \\
\hline Enterococcus faecalis ATCC 29212 & 15.6 & 15.6 & 15.6 & 15.6 & 1.0 Amp \\
\hline Bacillus subtilis ATCC 6633 & 15.6 & 15.6 & 15.6 & 7.8 & $2.0^{\mathrm{Amp}}$ \\
\hline Pseudomonas aeruginosa ATCC 27853 & 15.6 & 15.6 & 7.8 & 15.6 & 4.0 $\mathrm{Ami}$ \\
\hline Escherichia coli ATCC 25922 & 15.6 & 15.6 & 15.6 & 15.6 & $2.0^{\mathrm{Ami}}$ \\
\hline Klebsiella pneumoniae NCIMB 9111 & 15.6 & 15.6 & 15.6 & 15.6 & $2.0^{\mathrm{Ami}}$ \\
\hline Candida albicans ATCC 10259 & 7.8 & 7.8 & 7.8 & 7.8 & $3.1^{\text {Nys }}$ \\
\hline
\end{tabular}

Table 4. Antimicrobial activity of the methanol and chloroform extracts of aerial parts and roots of E. palmatum.

$$
\text { Amp Ampicillin; Ami Amikacin; Nys Nystatin }
$$

role in inhibiting DNA or RNA synthesis [25]. The methanol extract of roots, which contained catechins, also inhibited the growth of tested microorganisms

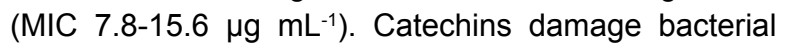
membranes and induce leakage of small molecules. Although it was reported that catechins have greater activity against Gram-positive than Gram-negative bacteria [25], in our study the methanol extract of roots restrained the growth of both bacterial groups. This activity is probably based on a synergistic activity of phenolic compounds.

On the other hand, non-polar chloroform extracts of aerial parts or roots also showed an antimicrobial effect. The chloroform extract of aerial parts significantly inhibited the growth of resistant Gram-negative bacteria $P$. aeruginosa (MIC $7.8 \mu \mathrm{g} \mathrm{mL}^{-1}$ ). Falcarinol, linoleic acid and palmitic acid, the main compounds in the chloroform extract of the aerial parts, exert antimicrobial activity [26,27]. Unsaturated fatty acids such as linoleic acid inhibit bacterial fatty acid synthesis by blocking bacterial enoyl-acyl carrier protein reductase (Fabl) which is essential for production of lipidcontaining components such as cell membranes [28]. It has been previously reported that octanoic acid, one of the main compounds in the chloroform extract of the roots, also restrains bacterial growth [29]. Other components in the root chloroform extract were saturated alcohols, which have an antimicrobial activity that depends on their carbon chain length [30]. The greatest growth inhibition activity is seen in long-chained fatty alcohols with an aliphatic carbon chain of 12 or 13 carbon atoms. The fatty alcohols with aliphatic chains of fewer than 7 carbon atoms have no activity, and alcohols with chains longer than 17 carbon atoms have very low antimicrobial effect [31]. Considering the structure of fatty alcohols identified in the chloroform extracts of $E$. palmatum, it can be presumed that these compounds contribute to the observed antimicrobial activity.

\subsection{Antioxidant activity}

The antioxidant activity of secondary metabolites, especially phenolic compounds, is based on their ability to donate hydrogen atoms or electrons, chelate metal cations or scavenge free radicals [18,32]. The ferric reducing antioxidant power (FRAP) assay indicates the total antioxidant potential of the investigated extract. The total antioxidant potential of the methanol extract of aerial parts was $0.2 \pm 0.0 \mathrm{mmol} \mathrm{Fe}^{2+} \mathrm{g}^{-1}$ and of the methanol extract of roots was $0.1 \pm 0.0 \mathrm{mmol}$ $\mathrm{Fe}^{2+} \mathrm{g}^{-1}$ (Table 1). The reducing power of the methanol extract of aerial parts found in this study was similar to that of the water extract of leaf of $E$. bornmuelleri $\left(0.25 \mathrm{mmolFe}^{2+} \mathrm{g}^{-1}\right)$. The reducing power of the methanol extract of roots of $E$. palmatum was higher than the activity of the water extract of roots of $E$. bornmuelleri (0.05 mmol $\mathrm{Fe}^{2+} \mathrm{g}^{-1}$ ) [20]. In the DPPH assay, the reactivity of potential antioxidant with stable, free $\mathrm{DPPH}$ radical is measured. The concentration of the extract that reduces $50 \%$ of the DPPH radical was $0.6 \pm 0.0 \mathrm{mg} \mathrm{mL}^{-1}$ for the methanol extract of aerial parts and $0.7 \pm 0.0 \mathrm{mg} / \mathrm{ml}$ for the methanol extract of roots. Previously reports of different extracts of E. caucasicum Trautv. showed analogous DPPH scavenging activity $\left(0.4-0.8 \mathrm{mg} \mathrm{mL}^{-1}\right)$ [33]. The methanol extract of aerial parts inhibited highly reactive and toxic $\mathrm{OH}^{\cdot}$ radicals in the concentration of $0.5 \mathrm{mg} \mathrm{mL}^{-1}$ and the methanol extract of roots did so in the amount of $0.3 \mathrm{mg} \mathrm{mL}^{-1}$. The antioxidant activity of E. palmatum methanol extracts was not significant in 
comparison with the control antioxidant rutin, but was comparable to the previously-investigated antioxidant activity of other species of this genus.

\section{Conclusions}

Our research showed that methanol and chloroform extracts of aerial parts or roots of E. palmatum possessed significant antimicrobial activity against Gram-positive and Gram-negative bacteria. The antimicrobial effect of the methanol extract of aerial parts is probably based on the flavonoid content; the activity of the methanol extract of roots is likely to be due to catechins and other phenolic constituents. Non-polar chloroform extracts also inhibited the growth of the tested microorganisms. The chloroform extracts contained polyacetylene, fatty alcohols, saturated and unsaturated fatty acids, all of which have proven antimicrobial activity.

\section{Acknowledgements}

This work was financially supported by the Ministry of Education, Science and Technological Development of the Republic of Serbia, Project No. 173021.

\section{References}

[1] Calviño C.I., Martínez S.G., Downie S.R., The evolutionary history of Eryngium (Apiaceae, Saniculoideae): Rapid radiations, long distance dispersals, and hybridizations, Mol. Phylogenet. Evol., 2008, 46, 1129-1150

[2] Küpeli E., Kartal M., Aslan S., Yesilada E., Comparative evaluation of the anti-inflammatory and antinociceptive activity of Turkish Eryngium species, J. Ethnopharmacol., 2006, 107, 32-37

[3] Mekhora C., Muangnoi C., Chingsuwanrote P., Dawilai S., Svasti S., Chasri K., et al., Eryngium foetidum suppresses inflammatory mediators produced by macrophages, Asian Pac. J. Cancer Prev., 2012, 13, 653-664

[4] Kartnig T., Wolf J., Flavonoids from the aboveground parts of Eryngium campestre, Planta Med., 1993, 59, 285

[5] Le Claire E., Schwaiger S., Banaigs B., Stuppner H., Gafner F., Distribution of a new rosmarinic acid derivative in Eryngium alpinum L. and other Apiaceae, J. Agric. Food Chem., 2005, 53, 43674372

[6] Cádiz-Gurrea M.L., Fernández-Arroyo S., Joven J., Segura-Carretero A., Comprehensive characterization by UHPLC-ESI-Q-TOF-MS from an Eryngium bourgatii extract and their antioxidant and anti-inflammatory activities, Food Res. Int., 2013, 50, 197-204

[7] Cavaleiro C., Gonçalves M.J., Serra D., Santoro G., Tomi F., Bighelli A., et al., Composition of a volatile extract of Eryngium duriaei subsp. juresianum (M. Laínz) M. Laínz, signalized by the antifungal activity, J. Pharm. Biomed. Anal., 2011, 54, 619622

[8] Çelik A., Aydinlik N., Arslan I., Phytochemical constituents and inhibitory activity towards

methicillin-resistant Staphylococcus aureus strains of Eryngium species (Apiaceae), Chem. Biodivers., 2011, 8, 454-459

[9] Chater A.O., Eryngium L., In: Tutin T.G., Heywood V.H., Burges N.A., Moore D.M., Valentine D.H., Walters S.M., et al. (Eds.),Flora Europaea, Cambridge University Press, London, 1968, Vol. 2, 320-324

[10] Gibbons S., Phytochemicals for bacterial resistance - strengths, weaknesses and opportunities, Planta Med., 2008, 74, 594-602

[11] Ziech D., Anestopoulos I., Hanafi R., Voulgaridou G.P., Franco R., Georgakilas A.G., et al., Pleiotrophic effects of natural products in ROSinduced carcinogenesis: the role of plant-derived natural products in oral cancer chemoprevention, Cancer Lett., 2012, 327, 16-25

[12] Martin K.W., Ernst E., Herbal medicines for treatment of bacterial infections: a review of controlled clinical trials, J. Antimicrob. Chemother., 2003, 51, 241-246

[13] Makkar H.P.S., Hagerman A., Harvey-Mueller I., Quantification of Tannins in Tree Foliage - A Laboratory Manual, FAO/IAEA, Vienna, 2000

[14] Adams R.P., Identification of essential oil components by gas chromatography/quadrupole mass spectroscopy, Allured Publishing Corporation, Illinois, 2001

[15] Clinical and Laboratory Standards Institute, Performance Standards for Antimicrobial Susceptibility Testing, 17th Informational Supplement, CLSI document M100-S17, ISBN 1-56238-625-5, 2007

[16] Benzie I.F., Strain J.J., The Ferric Reducing Ability of Plasma (FRAP) as a Measure of "Antioxidant Power": The FRAP Assay, Anal. Biochem., 1996, 239, 70-76 
[17] Szőllősi R., Varga Szőllősi I., Total antioxidant power in some species of Labiatae (Adaptation of FRAP method), Act. Biol. Szeg., 2002, 46(3-4), 125-127

[18] Bondet V., Brand-Williams W., Berset C., Kinetics and Mechanisms of Antioxidant Activity using the DPPH' Free Radical Method, Lebensm.-Wiss. Technol., 1997, 30, 609-615

[19] Lee J.C., Kim J., Park J.K., Chung G.H., Jang Y.S., The antioxidant, rather than prooxidant, activities of quercetin on normal cells: quercetin protects mouse thymocytes from glucose oxidase-mediated apoptosis, Exp. Cell Res., 2003, 291, 386-397

[20] Dalar A., Konczak I., Botanicals from Eastern Anatolia region of Turkey: Antioxidant capacity and phenolic constituents of endemic herbal medicines, J. Herb. Med., 2012, 2, 126-135

[21] Kikowska M., Budzianowski J., Krawczyk A., Thiem B., Accumulation of rosmarinic, chlorogenic and caffeic acids in in vitro cultures of Eryngium planum L. Acta Physiol. Plant., 2012, 34, 2425-2433

[22] Tegos G., Stermitz F.R., Lomovskaya O., Lewis K., Multidrug pump inhibitors uncover remarkable activity of plant antimicrobials, Antimicrob. Agents Chemother., 2002, 46, 3133-3141

[23] Akroum S., Bendjeddou D., Satta D., Lalaoui K., Antibacterial activity and acute toxicity effect of flavonoids extracted from Mentha longifolia, Am. Eurasian J. Sci. Res., 2009, 4, 93-96

[24] Cowan M.M., Plant products as antimicrobial agents, Clin. Microbiol. Rev. 1999, 12, 564-582

[25] Cushnie T.P., Lamb A.J., Antimicrobial activity of flavonoids, Int. J. Antimicrob. Agents, 2005, 26, 343-356
[26] Kobaisy M., Abramowski Z., Lermer L., Saxena G. Hancock R.E., Towers G.H. et al., Antimycobacterial polyynes of devil's club (Oplopanax horridus), a North American native medicinal plant, J. Nat. Prod., 1997, 60, 1210-1213

[27] Kabara J.J., Swieczkowski D.M., ConleyA.J., Truant J.P., Fatty acids and derivatives as antimicrobial agents, Antimicrob. Agents Chemother., 1972, 2, 23-28

[28] Zheng C.J., Yoo J.S., Lee T.G., Cho H.Y., Kim Y.H., Kim W.G., Fatty acid synthesis is a target for antibacterial activity of unsaturated fatty acids, FEBS Lett., 2005, 579, 5157-5162

[29] Hulánková R., Bořilová G., In vitro combined effect of oregano essential oil and caprylic acid against Salmonella serovars, Escherichia coli 0157:H7, Staphylococcus aureus and Listeria monocytogenes, Acta Vet. Brno, 2011, 80, 343-348

[30] Kubo I., Muroi H., Kubo A., Naturally occurring antiacne agents, J. Nat. Prod., 1994, 57, 9-17

[31] Togashi N., Shiraishi A., Nishizaka M., Matsuoka K., Endo K., Hamashima H., et al., Antibacterial activity of long-chain fatty alcohols against Staphylococcus aureus, Molecules, 2007, 12, 139-148

[32] Afanas'ev I.B., Dorozhko A.I., Brodskii A.V., Kostyuk V.A., Potapovitch A.I., Chelating and free radical scavenging mechanisms of inhibitory action of rutin and quercetin in lipid peroxidation, Biochem. Pharmacol., 1989, 38, 1763-1769

[33] Nabavi S.M., Nabavi S.F., Alinezhad H., Zare M., Azimi R., Biological activities of flavonoid-rich fraction of Eryngium caucasicum Trautv., Eur. Rev. Med. Pharmacol. Sci., 2012, 16(3), 81-87 